\title{
EFFECT OF WASTE WATER ON VEGETABLE PRODUCTION
}

\author{
ADAMS B.A, OSIKABOR B, OLOMOLA A AND ADESOPE, A.A.A \\ College of Forestry Jericho Ibadan \\ Email: adamcinjoy@yahoo.com
}

\begin{abstract}
This experiment was carried out in Ibadan, Oyo State Nigeria purposively selecting four sites where waste waters were used for growing vegetables. Water, soil and leafy vegetables (Amarantus) samples were collected randomly form each siute and subjected to analysis for heavy metals such as Lead, Nickel, Arsenic, Cadmium and Mercury at laboratories in Obafemi Awolowo University, Ile-Ife for leafy vegetables and University of Ibadan for soil and water analysis. The result showed that there are significant difference with the respect of contaminant presence in the waters and soils samples. With regard to the analysis results, specimen $C$ (Eleyele dam) vegetable had the highest percentage value of Lead $(0.28 \%)$ Arsenic (62.5\%) and Cadmium (0.92\%) which was influenced by the amount of heavy metals taken from both soil and water.
\end{abstract}

Key words: waste water, vegetable production

\section{INTRODUCTION}

People can not do but eat vegetable either raw or dished with one food or the other because it serves as source of vitamin and protein. Vegetables are water loving plant, before it could be grown, source of water supply must be considered. Most livelihood activities depend on the availability of water. However, in many semiarid and arid regions of the world, freshwater is a scarce resource. Fresh surface water is usually available in sufficient quantities during the rainy season. But, the rainy season may only last for 4 months during which rainfall can be erratic, necessitating irrigation. Water for irrigation is also required for the long dry season. Groundwater may be expensive to access because of low water tables that translate into high costs associated with drilling wells and pumping the water. Seeking other sources of water to support livelihoods therefore become critical to the question of poverty reduction. Near urban centers wastewater is often available year-round in sufficient quantities.

It is in this context that wastewater needs to be studied as natural capital required to sustain the means of living in arid and semiarid, drought-prone areas. In many arid and semiarid regions, wastewater use may either be the only option, or the only economically viable option available to many groups of people. Livelihood activities directly depend on wastewater are practiced by diffeent social groups on different scales and include (but are not limited to) agriculture, agro-forestry, livestock rearing, aquaculture, floriculture, and the washing of clothes. Activities indirectly dependent on wastewater include the sale of seeds, pesticides and other inputs to wastewater farmers, rental of harvest machinery or equipment, agricultural labour, services related to the transportation of produce to markets, marketing produce, animal husbandry with purchased wastewater-irrigated fodder and the provision of fish seedlings for pisciculture (Shuval et al 1986). The amount of wastewater produce depends on the population of a city or town. Industrial and domestic liquid wastes are frequently channeled either into the same sewerage system (f a sewerage system exists) or into the same open drains. The number and types of livestock the household owns will influence the type of wastewater-related activities in which they engage (Buechler and Devi, 2002). Wastewater quality is affected by the volume and types of industrial effluent released into the sewerage system or drains, and the degree of dilution with domestic water and natural sources of flow where these exist. The wastewater is either released untreated, after 
partial treatment, or after more complete treatment (to the secondary or tertiary levels), into drains, into channels, and then frequently into rivers.

Water is the principal constituent of plant growth. Soil nutrients are dissolved by water to absorbable soluble elements for plant, water cool down the soil temperature and increase the relative humidity around the plants. Water plays an important role in plant growth and development from the seedling stage to maturity stage.In dry season, there is shortage of rainfall to sustain plant, during this period clean water may be expensive to get because of low water tables that translate into the high cost associated with drilling wells and pumping the water, the alternative use of water for irrigation should be found. In local and urban areas, there are large production of waste water, wastewater from homes, industries which are channel into the flowing water around them. This waste water contain pollutants like, pathogen, heavy metals, debris e.t.c which can be up taken by plants and cause serious effect on human health when eaten especially at raw stage. It was reported by FAO (2002) that most of the live hood activities depends on the availability of waste water for irrigation which may be legal or illegal in the country.

The health effect of waste water on farmers, agricultural consumers of waste waterirrigated produce have been studies in some areas in part of the world like Ghana, Serrialone, South-Africa, Israel and other countries. (Blumenthal et al., 2000).So therefore, it is very necessary to know the effect caused by the use of waste water in our environment for irrigation of the vegetables consumed every day by the people in Ibadan. This research work was designed to evaluate the level of heavy metals in vegetable produced with wastewater in Ibadan.

\section{MATERIAL AND METHODS}

The study was carried out in Ibadan, Oyo State Nigeria. Four sites where waste water was used for growing vegetables were purposively chosen. The areas are: sample A Odogbo Barrack, Sample B University of Ibadan, sample C Eleyele (dam). and sample D Odo-ona. Water, soil and leafy vegetables (Amarantus) samples were collected randomly form each site for analysis. The samples were taken to laboratory at Obafemi Awolowo University IleIfe and University of Ibadan for the analysis. The raw samples was first taken to Agricultural laboratory and arched before analyzing for heavy metals. Vegetable leaves were subjected to the following operations, each raw sample were pounded with laboratory mortar, and 2 grammes of samples was weighed in a platinum crucible. It was later transferred into a muffler furnace and ash at $6000 \mathrm{C}$ for 3 hours. It was removed and allowed to cool in a desiccators, then $5 \mathrm{ml}$ of 6 normal Hydrochloride acid (HCL) was added and allow to digest for 30 minutes.

The digested substances were filtered into $50 \mathrm{ml}$ conical flask, the filtrate was made up to $50 \mathrm{ml}$ with distilled water and it was shaken vigorously and transfer to control science laboratory for mineral determination with the aid of Atomic Absorption Spectrophotometer (AAS), with model, Alpha 4 and serial no of 4,200. Also soil and water analysis were conducted to determine the volume of heavy metals. The soil samples were collected from each location and took to soil laboratory at University of Ibadan for the determination of heavy metals. The machine used was Atomic Absorption Spectrophotometer (AAS).

\section{RESULTS AND DISCUSSION}

The results in the Table 1 are the values percentage of concentration of the heavy metal in vegetable samples. Vegetables from Eleyele dam has the highest value of Lead $(0.28 \%$, vegetable grown in Odo-ona river only had low level of Nickel. While vegetable grown around Eleyele dam has the highest amount of Arsenic (62.5\%), and cadmium (0.92\%). All the sample tested did not show any trace of Mercury. It was reported W.H.O. (2000) that the 
caused the consumption of food crops irrigated with wastewater include, constant without loss of apatite, and damage caused by the micro organism. The result provided information on the presence of some heavy metal namely Lead, Arsenic, and Cadmium in vegetables grown around Eleyele. From the point of view, different rivers from different places were channel into Eleyele dam which aid the deposition of these heavy chemicals and they are very harmful to the body when they are been consumed especially at raw stage.

Table 1: Percentage of heavy metal in the each vegetable sample

\begin{tabular}{llllll}
\hline Specimen & $\begin{array}{l}\text { Lead } \\
(\boldsymbol{\%})\end{array}$ & $\begin{array}{l}\text { Nickel } \\
(\boldsymbol{\%})\end{array}$ & $\begin{array}{l}\text { Arsenic } \\
(\boldsymbol{\%})\end{array}$ & $\begin{array}{l}\text { Cadmium } \\
(\boldsymbol{\%})\end{array}$ & $\begin{array}{l}\text { Mercury } \\
(\boldsymbol{\%})\end{array}$ \\
\hline $\mathrm{A}$ & - & - & 0.36 & $0.41 \pm 0.3$ & - \\
$\mathrm{B}$ & - & - & - & 0.71 & - \\
$\mathrm{C}$ & 0.28 & - & 62.5 & 0.92 & - \\
$\mathrm{D}$ & 0.03 & 0.70 & - & 0.71 & - \\
\hline
\end{tabular}

Table 2 shows the value of heavy metals in water samples. Site Sample A (Barrack water) had highest value of Lead $(0.000052 \%)$ followed by specimen D Odo-ona water $(0.000043 \%)$. Site sample C (Eleyele dam) had lowest value of Lead (0.00038), site sample A (Barrack water) had highest value of Arsenic (0.000021) followed by site sample D (Odoona water) Site Sample B (UI water) had lowest value of Arsenic $(0.00014 \%)$.

Site sample Barracks water, UI water and Eleyele Dam had highest value of Arsenic $(0.000004 \%)$ and site sample C (Eleyele dam)had lowest value $(0.000072 \%)$ of Cadmium followed by site sample A (Barracks water) $(0.000057 \%)$ Cadmium. From this result, it shows that specimen A (barracks water) had highest value of Lead, Arsenic and Cadmium at the level that are harmful to human health.

Table 2: Percentage concentration of heavy metals in each water sample

\begin{tabular}{llllll}
\hline Specimen & $\begin{array}{l}\text { Lead } \\
(\boldsymbol{\%})\end{array}$ & $\begin{array}{l}\text { Nickel } \\
(\boldsymbol{\%})\end{array}$ & $\begin{array}{l}\text { Arsenic } \\
(\boldsymbol{\%})\end{array}$ & $\begin{array}{l}\text { Cadmium } \\
(\boldsymbol{\%})\end{array}$ & $\begin{array}{l}\text { Mercury } \\
(\boldsymbol{\%})\end{array}$ \\
\hline $\mathrm{A}$ & 0.000052 & 0.000021 & 0.00004 & 0.000061 & - \\
$\mathrm{B}$ & 0.00041 & 0.000017 & 0.000004 & 0.000006 & - \\
$\mathrm{C}$ & 0.000038 & 0.000041 & 0.000003 & 0.000072 & - \\
$\mathrm{D}$ & 0.000043 & 0.000019 & 0.000004 & 0.000057 & - \\
\hline
\end{tabular}

Table 3 presents the value of heavy metals in soil sample collected from study site. Site sample B (UI soil) had highest value of Lead (0.00038\%), followed by site sample C (Eleyele dam) $(0.000345 \%)$ site sample A (Barracks soil) had highest value of cadmium (0.00009) followed by site sample C (Eleyele dam) (0.000085) Site sample D (Odo-ona soil) had highest value of Nickel (0.000858) following site sample A (0.000545) and site sample D had lowest value from this analysis result, it was clearly showed that soil sample gotten from Odo-ona had lowest percentage value or Arsenic, Cadmium and Nickel. This does influence the nutrient taken by the vegetable collected from this site. Heavy metals are readily presence in the soil at a given volume at given place, the deficiency and excess can be balanced by the use of fertilizers and manure, (Fesilkerea 1998). Heavy metal presence in the soil depends on the type of waste water used for irrigation and the soil amelioration added to the soil. (Retal and Boatol, 1994).

Though, most of the heavy metals are readily present in the soil, but their concentration can be influenced or controlled by limiting and manure and fertilizer application. The addition of manure, lime and fertilizer to provide elements needed for plant growth also influence the change in $\mathrm{Ph}$ value of the soil specimen. Fruits and vegetables 
raised from contaminated soil may also pose a problem if they are not properly washed or peeled before eaten.

Table 3: Percentage Concentration Of Heavy Metals In Each Soil Sample

\begin{tabular}{llllll}
\hline Specimen & $\begin{array}{l}\text { Lead } \\
(\boldsymbol{\%})\end{array}$ & $\begin{array}{l}\text { Nickel } \\
(\boldsymbol{\%})\end{array}$ & $\begin{array}{l}\text { Arsenic } \\
(\boldsymbol{\%})\end{array}$ & $\begin{array}{l}\text { Cadmium } \\
(\boldsymbol{\%})\end{array}$ & $\begin{array}{l}\text { Mercury } \\
(\boldsymbol{\%})\end{array}$ \\
\hline $\mathrm{A}$ & 0.00037 & 0.00011 & 0.00009 & 0.000545 & - \\
$\mathrm{B}$ & 0.00038 & 0.000096 & 0.000085 & 0.00052 & - \\
$\mathrm{C}$ & 0.000345 & 0.00008 & 0.00007 & 0.000585 & - \\
$\mathrm{D}$ & 0.00029 & 0.000065 & 0.000045 & 0.00049 & - \\
\hline
\end{tabular}

\section{CONCLUSION AND RECOMMENDATION}

The study revealed that vegetable which are raised with polluted water had highest significant value of heavy metals which are very harmful to health when they are been consumed at raw stage. Specimen C (Eleyele Dam) the vegetable had high volume of heavy metals. Specimen B (U.I) vegetable had only trace of Cadmium $(0.1776 \%)$ and had no traces of the rest metals. Water collected from Specimen A (barracks) had highest value of all the heavy metals but had traces of Arsenic and cadmium in the vegetable sample collected. The heavy metal in the water and soil does not affect the vegetable grown form this site due to the use of manure. Through the soil is reality contain heavy metals but the acidity and alkalinity can be altered with the use of fertilizer and manure. Plants absorb nutrient from soil in soluble from and water is a medium that dissolve soil nutrient into the soluble absorbable element for plant root. During this process, both elements in the soil and water collaborated and affect plant. Fertilizing and manure application at proper ratio can used to balance the deficiency of the soil nutrient available for plant.

Based on the findings, the following recommendations were made Specimen $\mathrm{C}$ (Eleyele dam) had high volume of heavy metals in the vegetable collected from the site. This shows that, Eleyele dam vegetables are not good for consumption especially at raw stage because of problems cause by heavy metals to the body. Also, Barracks water had low volume of heavy metals in the vaegetable collected from the site. The vegetables are good for consumption because of low level of the heavy metals.

\section{REFERENCES}

Blumenthal, U., Mara, D.D., Peasey, A., Ruiz-Palacios, G and Stott, R. (2000). Guidelines for the microbiological quality of treated wastewater used in agriculture: recommendation for revising WHO guidelines. Bulleting of the World Health Organization 78(9), $1104-1116$.

Buechler, S., Devi, G. and Raschid-Sally, L. (2002). Livelihoods and Wastewater irrigated agriculture along the Musi River in Hyderabad City, Andhra Pradesh, India. Urban Agriculture Magazine 8, 14-17.

Ensink, J.h.J., Van der Hoek, W., Matsuno, Y., Munir, S. and Aslam, M.R. (2003): The use of Untreated wastewater in Peri-urban Agriculture in Pakistan: Risks and Opportunities. IWMI Research Report no. 64, International Water Management Institute, Colombo, Sri Lanka. $22 \mathrm{pp}$.

F.A.O. (2002): Waste Water Recycling, Dofine India. Waste Recycling Magazine 5, 18-22.

Feenstra, S., Hussain, R. and van der Hoek, W. (2000): Health Risks of Irrigation with Untreated Urban Wastewater in the Southern Punjab, Pakistan. IWMI Pakistan Report no. 107, international Water Management Institute, Lahore, Pakistan.

H.W.O. (2000): Food Crop Production in Ghana. Pp 20-22.

Shuval, H.I., Adin, A., Fattal, B., Rawitz, E. and Yekutiel, P. (1986): Wastewater Irrigation in Developing countries-Health Effects and Technical solutions. UNDP Project Management Report. World Bank Technical Paper no. 51, Washington, DC. 